A N NALES

UNIVERSITATIS MARIAE CURIE-SKŁODOWSKA

LUBLIN - POLONIA

VOL. XXXV

SECTIO FF

$1-2017$

\title{
KATARZYNA KLEWINOWSKA
}

Uniwersytet w Białymstoku

\section{Maryla Wolska jako twórczyni liryki kobiecej}

Maryla Wolska as the Author of Women's Lyric Poetry

\section{SYLWETKA TWÓRCZA MARYLI WOLSKIEJ}

Przełom wieku i czasy po pierwszej wojnie będą obfitowały $\mathrm{w}$ talenty poetyckie. Listę najwybitniejszych poetek tego okresu otwiera Maryla Wolska (Borkowska, Książek-Czermińska i Phillips, 2000:61).

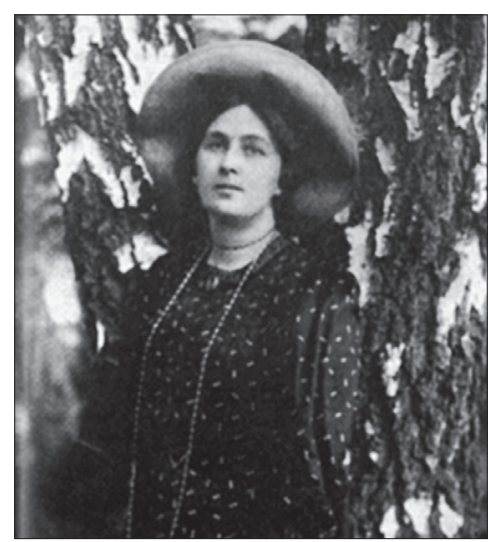

Maryla Wolska w Storożce

Maryla Wolska urodziła się 13 marca 1873 roku we Lwowie. Od najmłodszych lat obcowała ze sztuką. Pochodziła z bardzo wykształconej rodziny. Z otoczenia, w którym dorastała, wyniosła nie tylko obyczaje, idee czy patriotyzm, ale także: 
[...] pewne strony ujemne: najpierw pewien dramatyczny pesymizm, którego nie mogło zrównoważyć pogodne usposobienie ojca ani odporny i czynny charakter jej matki. Drugą szkodą tej atmosfery był pewien eufemistyczny kult zewnętrznego piękna, przez którego szminkę trudno się było doskrobać nieraz do własnej prawdy (Pawlikowski, 1914:214-215).

Poetka była uzdolniona w kierunku artystycznym. Malarstwo stanowiło początkowo najbardziej przyszłościowe przedsięwzięcie. Jednak, jak zauważa Stanisław Sierotwiński (1963:17), „mimo zachęt i oznak uznania nauczycieli Maryla zniechęciła się i zawiodła oczekiwania" przede wszystkim rodziców, którzy włożyli w rozwój jej talentu wysiłek oraz środki finansowe. Z uprawiania sztuki Wolska do końca nie zrezygnowała. Z czasem zaczęła publikować prace w „Tygodniku Polskim", w którym w roku 1899 umieszczono takie jej rysunki, jak: Danuśka (do powieści Henryka Sienkiewicza Krzyżacy), Paderewski, Matka Boża, Studium, Najświętsza Panna.

W 1894 roku poetka poślubiła Wacława Wolskiego - pochodzącego z dobrego domu majętnego inżyniera, wynalazcę i przedsiębiorcę naftowego. Mieli pięcioro dzieci (trzech synów i dwie córki), które starali się wykształcić jak najlepiej: najstarszego syna Ludwika, młodszych - Kazimierza i Juliusza, córkę Beatę (Obertyńską) - poetkę i prozatorkę, oraz najmłodszą z całego rodzeństwa Anielę, która wyszła za mąż za Michała Pawlikowskiego i została malarką. Wolska była dobrą żoną i matką, ale jeszcze lepszą poetką. Pięcioro dzieci, mąż i prace związane z utrzymaniem domu nie przeszkodziły jej w rozwijaniu talentów i spełnianiu marzeń.

Jej debiut literacki przypada na rok 1893. Miała wówczas dwadzieścia lat. Pierwsze wydane tomiki wierszy, datowane na lata 1901 i 1903, zostały pochlebnie zrecenzowane i docenione na arenie literackiej. Jako kolejne ukazały się: Thème Varié (1901), Symfonia jesienna (1901), Święto słońca (1903), Z ogni kupalnych (1903), a także dramat o prawdzie Swanta (1909). Wolska publikowała również w takich czasopismach, jak „Lamus”, „Krytyka” czy „Irys”. Ostatni tomik z roku 1929 pt. Dzbanek malin spotkał się z najlepszymi komentarzami i wyrazami uznania: „Posypały się liczne i wszystkie bez wyjątku bardzo pochlebne recenzje, dające często okazję do przypomnienia całej twórczości poetki" (Sierotwiński, 1963:52). W tej publikacji pojawiły się wiersze z lat 1902-1905, 1907, aż do 1928 roku.

Pisarka zajmowała się także thumaczeniami. Pierwszy przekład zamieszczony został w 1902 roku w „Słowie Polskim”. Sierotwiński zauważył, że:

[...] wszystkie przekłady, jakich Wolska dokonywała, mają jedną cechę wspólną: wynikały zawsze z upodobania do pisarzy czy utworu, z pokrewieństwa tematycznego z własnymi poglądami czy nastrojami, wykazują zwykle po prostu wyraźne podobieństwo z własną jej oryginalną twórczością czy też z kolei na nią wpływają (1963:22). 
Być może to, co czytała w obcym języku, wpłynęło na tematykę jej wierszy. Pierwsze utwory, takie jak Cieniom i Na starym chórze, zostały opublikowane w „Tygodniku Ilustrowanym”. Przyczyniły się one do stworzenia przyjacielskich relacji z Elizą Orzeszkową, która - zachwycona talentem Wolskiej - postanowiła nawiązać z nią znajomość. Zaczęła się wówczas bardzo serdeczna korespondencja między kobietami. Poetka utrzymywała także bliskie kontakty z innymi znanymi pisarzami, np. z Leopoldem Staffem, Stefanem Żeromskim i Marią Konopnicką. Ten pierwszy w pewnym sensie pełnił funkcję krytyka literackiego Wolskiej, bowiem wielokrotnie prosiła go o porady i liczyła się z jego zdaniem. Według Sierotwińskiego zwyczajem było, że „Wolska i Staff dawali sobie wzajemnie do osądu swe dzieła i że koleżeńską krytykę cenili" (1963:40).

Poetka od początku bała się surowej oceny większego grona odbiorców, ponieważ mogłoby to zupełnie zmienić jej stosunek do literatury i tworzenia. Pierwsze publikacje Wolskiej podpisane były pseudonimem „Zawrat”, a późniejsze „D-moll”. Wprowadzało to w dezorientację recenzentów co do płci autora. Poetka nie chciała ujawniać swoich personaliów, aby nie kompromitować się na arenie literackiej. Być może zdecydowało o tym również pochodzenie ze znanej i wykształconej rodziny, w której niemal każdy odnosił sukces artystyczny. Matka Wanda, z domu Moneé, narzeczona wcześnie zmarłego Artura Grottgera, była uzdolnioną muzycznie i literacko autorką wielu książek dla dzieci, zaś ojciec Karol Młodnicki był artystą, malarzem i nauczycielem rysunku w kilku szkołach lwowskich.

Z czasem, gdy Wolska otrzymywała coraz więcej pozytywnych komentarzy, zaczęła podpisywać się jako „Maryla W.”. Przekonanie o słuszności tworzenia rodziło się w niej bardzo powoli i stale ewoluowało. Małymi krokami sama musiała dojść do tego, że jest to nie tylko pasja czy zamiłowanie, ale przede wszystkim sposób na życie. Po licznych pochlebnych recenzjach zaczęła odchodzić od używania pseudonimów, aby pokazać, że to ona jest autorką chwalonych wierszy. Razem z Michałem Pawlikowskim redagowała czasopismo „Lamus”, które ukazywało się w latach 1909-1913. Tam publikowała utwory już pod własnym nazwiskiem, podczas gdy Pawlikowski nadal używał pseudonimu - „Marek”. Ten etap w życiu Wolskiej można uznać za apogeum twórczości, gdyż pisze wówczas nie tylko dla siebie, ale przede wszystkim dla czytelnika. Nie wstydzi się tego, co prezentuje - pokonała strach przed odrzuceniem i krytyką.

Oprócz wierszy pisała także opowiadania. Wydany w 1910 roku tom pt. Dziewczęta ponownie został podpisany pseudonimem - „Iwo Płomieńczyk”. Można tylko zastanawiać się, dlaczego uznana już poetka znowu zaciera ślad swojej tożsamości. Powodem mogły być obawy przed negatywnymi ocenami zbioru. Pisarki, które na przełomie wieków tworzyły pod męskimi pseudoni- 
mami, często miały kompleks związany z płcią i odbieraniem przez społeczeństwo kobiet, które chciały zaistnieć w życiu publicznym. Pomimo procesu feminizacji trudniej było im się wybić. Prawdopodobnie Wolska, podpisując się pod utworem jako mężczyzna, chciała zdobyć większą liczbę czytelników oraz przychylność recenzentów, bowiem dzieła autorstwa mężczyzn szybciej i efektywniej docierały do publiczności. Jak zauważył German Ritz, ,polska modernistyczna liryka kobieca drogę do własnej tożsamości musi sobie torować w dżungli męskiej wyobraźni seksualnej” (1999:121).

Można tylko domniemywać, czym był spowodowany fakt, że znana już z fantastycznych publikacji poetka ukrywa swoją osobę w tomiku opowiadań. Z pewnością Wolska wahała się, czy Dziewczęta nie zniszczą jej wizerunku, na który ciężko pracowała. Barbara Olech dostrzegła, że „kobieta - odrzucając maski i kostiumy narzucone jej przez model kultury patriarchalnej - odzyskuje swą prawdziwą tożsamość" (2002:252). Artystka wielokrotnie odrzucała kostium, jakim było ukrywanie personaliów i pisanie pod pseudonimami męskimi. W tym przypadku jednak po raz kolejny wybrała twórczość, która pozostawała w pozycji nadrzędnej do własnej tożsamości.

Ewa Kraskowska w artykule Kilka uwag na temat powieści kobiecej (1993:261) powołuje się na badania angielskiej krytyczki feministycznej Elaine Showalter, która wyróżnia trzy fazy historii literatury tworzonej przez pisarki: kobiecą (feminine, lata 1840-1880), feministyczną (feminist, lata 1880-1920) i żeńską (female, po roku 1920). Debiut i twórczość Wolskiej przypadały na lata 1893-1928, wobec czego, przywołując periodyzację Showalter, można uznać, że dorobek literacki poetki przypada na fazy feministyczną i żeńską. Autorka artykułu kwestionuje podział angielskiej krytyczki na fazy czy okresy na rzecz ,ponadczasowych postaw wobec tzw. kwestii kobiecej” (Kraskowska, 1993:261). Taka teza jest oczywiście słuszna, biorąc pod uwagę twórczość Wolskiej. Jej dorobek literacki przypada na drugą fazę, ale podejmowane tematy skupiają się wokół sfery żeńskiej, a więc „ku doświadczeniu kobiecemu jako źródłu sztuki; «żeńskość» to przede wszystkim biologizm i wynikająca z niego wizja świata oraz rodzaj uczuciowości” (Kraskowska, 1993:261).

Niestety, pomimo bogatego dorobku literackiego tuż po śmierci (1930) Wolska została uznana za „poetkę zapomnianą”, a jej twórczość pokryła się „głębszym cieniem niepamięci” (Sierotwiński, 1963:55).

\section{AFIRMACJA UCZUĆ W POEZJI KOBIECEJ}

Maryla Wolska, podobnie jak inne twórczynie liryki kobiecej, poruszała tematykę feministyczną w zupełnie innym wymiarze niż współcześni jej poeci. Pisząc o kobietach, zastanawiały się nie tylko nad cechami wyglądu i sposobem bycia, ale przede wszystkim opisywały przeżycia i uczucia bohaterek. Dla kobiety 
pisanie o innych kobietach jest rzeczą prostą, ponieważ „w kobiecie ogniskuje się historia wszystkich kobiet, ich dzieje osobiste, historia narodowa i ponadnarodowa" (Cixous, 1993:154). Na przełomie wieku XIX i XX było to osiągnięciem niewyobrażalnym. Poetki bardzo powoli dokonywały procesu ,feminizacji kultury” (Borkowska i in., 2000:106), który polegał nie tylko na działaniach społecznych, ale przede wszystkim na:

[...] pokazaniu, że świata biologii i kultury nie dzieli żadna zasadnicza granica, że wszystkie zjawiska biologiczne są przekładalne na język kultury, choćby za cenę naruszenia tabu, i że wielu zachowaniom kulturowym możemy przypisać naturalną, biologiczną motywację (Borkowska i in., 2000:106).

Poetki łamały konwenanse i często tematem ich wierszy stawały się miłość oraz intymność, prawdopodobnie dlatego, że był to ,gatunek przypisany symbolicznie sferze «kobiecości»» (Smyczyńska, 2011:85).

Wątki feministyczne dotyczą eksponowania cielesności oraz wyrażania uczuć i afirmacji przeżyć. Jeśli chodzi o cielesność, to liryka omawianych poetek czerpała ze świadomego postrzegania swojej kobiecości i pokazywania jej. Ważne było prezentowanie ich ciał, zachowań, sposobu bycia, wykonywanych czynności czy ukazywanie własnej kobiecości, a także wyraźne domaganie się niezależności w kontekście cielesnym (materialnym) oraz psychicznym (duchowym).

Ową duchową analizą warstwy człowieka zajmowali się prawie wszyscy moderniści. Jak zauważa Malwina Posner-Garfinowa, krytyczka literacka przełomu XIX i XX wieku, poetki młodopolskie starają się:

[...] przeniknąć każdą tajemnicę duszy, śledząc ją w każdym jej drgnieniu, słuchają każdego jej szeptu, baczą na jej wzloty. Podejmują w ten sposób zaniedbaną przez realizm dziedzinę życia i tęsknotę za poznaniem jej, pragnienie zespolenia się z nią zaznaczają często wyborem tematów oderwanych, którymi się realizm nie posługiwał (Wydrycka, 2006:113).

Także w twórczości Wolskiej widać odkrywanie tajemnic duszy i przedstawianie tych treści czytelnikowi.

W swoich utworach kobiety zwracały uwagę na ukazywanie przeżyć i uczuć bohaterki, żądzy wolności i wyborów miłosnych bądź erotycznych. Taką poezję wypada określić mianem emancypacyjnej. Nie chodzi jednak o emancypację w kontekście równouprawnienia, ale o niezależność w świecie, w którym prawo głosu należy się mężczyznom, a podlegać można jedynie ich wzorcom i wyobrażeniom. Owego wyzwolenia psychicznego potrzebowały postacie utworów lirycznych młodopolskich poetek. Kobieta w Szarej godzinie skarżyła się na coś, co tkwi w jej duszy, zadając ból, lecz nie chciała tej kwestii poruszać. Tym samym pisarka potwierdziła przekonanie o konieczności nieujawniania przeżyć: „Coś w piersi mej się skarży jak pieśń niewygrana,/ Coś, co słów się domaga dzień cały od rana" (Wolska, 2003:6). 
Twórczość poetek to opisywanie „doświadczenia inności (doświadczenia bycia «drugą płcią»), począwszy od sfery cielesności i związków uczuciowych, a kończąc na obyczajowości, szeroko rozumianych normach i hierarchizacji społeczno-politycznej" (Smyczyńska, 2011:88). Oprócz przedstawianych bohaterek problemy feministyczne dotyczą także sytuacji kobiet piszących w kontekście tego, w jaki sposób kreują postacie. Poetki „często nie identyfikują się z feminizmem nominalnie, choć dostrzegają i opisują krytycznie te problematyczne dla kobiet obszary, które leżą na sercu feministkom i feministom" (Smyczyńska, 2011:88).

Lucyna Kozikowska-Kowalik zauważyła, że poezja kobieca od zawsze wzbudzała wiele wątpliwości wśród krytyków i czytelników, chociażby ze względu na różnicę płci. Pisała:

[...] poetki pojawiały się w literaturze polskiej już od wieku XVI. Nie brakuje imion kobiecych wśród wierszopisów, poetów, prozaików, tłumaczy, pamiętnikarzy, dramaturgów, autorów literatury dla dzieci i młodzieży [...]. Do końca XIX wieku poezja pisana przez kobiety była tylko wejściem płci odmiennej w rolę męską. Brakowało tego, co u poetek młodopolskich nazywano «pierwiastkiem kobiecości» (1982:12-13).

Owe „pierwiastki kobiecości” widoczne są w twórczości Wolskiej.

\section{TEMATY FEMINISTYCZNE W TWÓRCZOŚCI MARYLI WOLSKIEJ}

Poetka w swoim dorobku literackim pozostawiła zbiory poezji, dramat i tom nowel. Najwięcej jednak było liryki o tematyce miłosnej:

Miłość jest odwiecznym tematem lirycznym; w poezji modernistycznej miała wyjątkowo uprzywilejowane miejsce, w kobiecej może jeszcze większą doniosłość i specjalne zabarwienie. W całej liryce Wolskiej dominować będą wiersze miłosne, zwierzenia przepojone tęsknotą i rezygnacją, utrzymane w tonie subtelnym, bez elementów zmysłowych, wyrażające marzenia o nieosiągalnym szczęściu (Sierotwiński, 1963:61).

Wielu krytyków literackich uważało Wolską za poetkę miłości, tęsknoty i zmysłowości. Adam Hutnikiewicz dostrzegł w niej również naturalność i delikatność:

[...] szczególnym jej urokiem była wysoka kultura wyrażania, naturalna wytworność, przejawiająca się w umiejętności tworzenia niezwykle sugestywnych poetycko obrazów, w doskonałej kompozycji, w wyraźnej stylizacji, wyzyskującej wyrazy rzadko używane, formy archaiczne (2008:154).

W Pisarkach polskich od średniowiecza do współczesności można przeczytać, że „była poetką delikatnych uczuć i nastrojów, zwiastunką niejasnych pragnień, podszytych erotyczną tęsknotą" (Borkowska i in., 2000:106). Z taką opinią 
należy się zgodzić, chociażby dlatego, że sądy o poetach formułowane są przede wszystkim przez pryzmat ich twórczości. To, o czym pisała Wolska, odnosiło się do płci żeńskiej. Bohaterki jej utworów rozważały kwestie miłości, przemijania czy tęsknoty. Choć niewiele w nich opisów wyglądu czy eksponowania kobiecego ciała, to odnaleźć można sporo cech, które wskazują na odwagę w wyrażaniu pragnień i potrzeb, prezentując tym samym kobiecość.

Tematy feministyczne $\mathrm{w}$ utworach poetki dotyczą sfery duchowej bohaterek. W wielu jej wierszach kobiety skarżą się, że coś bolesnego tkwi w ich duszach, jednak nie chcą powiedzieć, bądź nie wiedzą, co jest powodem udręczenia. Wolska stosuje dwa zabiegi: po pierwsze, tworzy postać, która nie chce ujawniać przyczyny rozdarcia wewnętrznego, aby czytelnik skupił się tylko na jej uczuciach i przemyśleniach. Pragnie pokazać, że kobieta to nie tylko piękne ciało, ale i dusza, a dylematy dotyczą jej uczuć i przeżyć, które są przedstawiane na pierwszym planie. Drugi sposób polega na tym, że bohaterka utworu sama nie wie, co jest przyczyną doświadczanego rozdrażnienia, a opis przeżyć ma być zagadką dla czytelnika. Ważne jest eksponowanie warstwy duchowej: przeżyć, przemyśleń czy rozterek. Takie konstruowanie wypowiedzi zmusza do refleksji nad problematyką utworu. Kobieta w Szarej godzinie nie wie, co powoduje jej tęsknotę. Zdaje sobie sprawę z tego, że choćby chciała zdradzić przyczynę, to niestety nie może tego zrobić:

\footnotetext{
Nie wiem, co to - lecz czuję, że mnie gnie tęsknota,

Że się z tym dusza moja zmaga i szamota,

I że mówić mi o tym nie wolno - nie wolno... (Wolska, 2003:6).
}

Niechęć bądź niemoc ujawnienia powodów rozdarcia wewnętrznego bohaterek liryki Wolskiej występuje w wielu innych utworach. W Wizji różanej kobieta zarzeka się, że nigdy nie powie, co czuje i co wywołuje w niej zakłopotanie:

Nie powiem nigdy nikomu

Nawet przez sen,

Nie powiem nigdy!

Zawarte poniosę usta i nawet wam nie powiem,

O róże...

O tym, co ze mną mrze

Nigdy nikomu nie powiem,

Nawet przez sen,

I ty mi -

Obiecaj, że...

Nigdy nie powiesz - nikomu! (Wolska, 2003:9).

Powyższy fragment wskazuje, że o tajemnicach postaci wie ktoś jeszcze. Bohaterka usilnie prosi ową osobę, aby wieści tych nikomu nie zdradzała. Podobna 
sytuacja ma miejsce w utworze Wiem ja... Do kobiety przyszło coś - jak twierdzi metaforycznie - z łąk. To nieznane zjawisko gra w jej duszy, lecz podmiot liryczny uważa, że nie warto o tym mówić: „lecz mi tego szkoda rzec,/ Szkoda rzec!...” (Wolska, 2003:13). Zwraca się do odbiorcy, dopytując, czy posiada on wiedzę na temat opisywanych uczuć. Zdaje sobie sprawę, że rozmówca wie, o czym ona myśli, dlatego oboje porozumiewają się za pomocą pytań, zagadek:

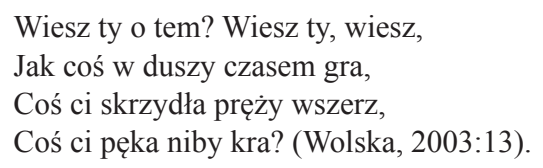

Konieczność nieujawniania doznań jest tematem nadrzędnym w liryce Wolskiej. Wszystko, co wprawia bohaterkę utworu w zakłopotanie, ma miejsce w duszy. Jest ona źródłem przemyśleń, przeżyć i rozdarcia. W wierszu $Z$ hymnów milczenia postać zwraca się do swojej duszy i ostrzega ją przez zbłądzeniem: „Duszo ty moja własna, harda duszo/ strzeż się zabłąkać sama w sobie!”, a dalej:

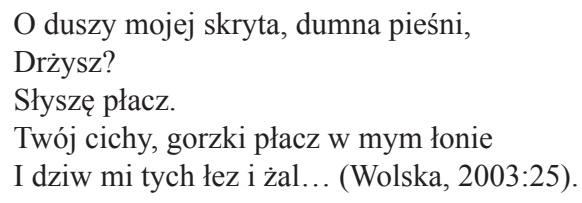

W utworze wielokrotnie powtarza się zwrot do duszy z zapytaniem, czy drży i czy płacze. Wyraża to tęsknotę i żal kobiety za czymś, co przeminęło. Uczucia ogarniają kobietę w taki sposób, że nie może się od nich wyzwolić. Stosuje różne zabiegi, szuka rozmaitych rozwiązań, każe duszy się zgubić albo wykrwawić tylko po to, aby nie odczuwać męczącej i determinującej tęsknoty. Wypowiedź kończy sformułowaniem:

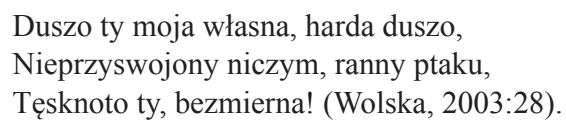

Poetka opisuje duszę jako dodatkowego bohatera i nadaje jej płeć. Płeć oczywiście jest żeńska, co wyraża niezależność i chęć dominacji nad płcią męską. W utworze pt. Dusza moja ukazuje duszę jako kobietę, w której zauważa piękno, zmysłowość i długie włosy splecione w warkocz:

Dusza moja na zawsze zostanie dziewczyną,

Co w las poszła o świcie, z dzbankiem, na jagody,

Krasą śmiała i ufna, że choć lata miną, 
Ona przetrwa w urodzie lic swych wiecznie młodej...

Dusza moja na zawsze zostanie dziewczyną.

Dusza moja w zielonym na warkoczach wianku,

Ścieżką idzie samotną, wolna jak ptak w lasie,

W pas się słońcu jednemu kłania o poranku,

Niby wicher swobodna nad życiem się niesie,

Dusza moja w zielonym na warkoczach wianku... (Wolska, 2003:39).

W innych utworach występują takie postacie, jak tytułowe: Kora, Beata Beatrix, Pani Aszperegowa, Penelope czy Kleopatra. Penelope czuje krzyk w piersiach. Beata Beatrix jest grzeczną, zmęczoną dziewczyną, która stale opuszcza ramiona. Pani Aszperegowa ma pod szyją złotą broszę. Nie bez przyczyny Wolska wybrała akurat te części ciała, bowiem szyja, piersi czy ramiona wskazują na erotyzm. Jest on także obecny w wierszu Śnito mi się..., w którym kobieta śni o pocałunkach: „śniły mi się na ustach chłodne usta twoje...” (Wolska, 2003:20). W cyklu Sześciu wierszy, w utworze czwartym, bohaterka nie wspomina o erotyzmie, lecz wyraża swoje uczucia do mężczyzny. Ku jego zdziwieniu, niewiasta ma odwagę po latach wyznać mu miłość. W innych wierszach poetki to silne uczucie wiążące dwoje ludzi jest obecne i dominuje nad erotyzmem. Sierotwiński zauważył, że:

[...] ten pozytywny walor idealnej miłości, na jawie beznadziejnej, a przecież decydującej o wewnętrznym życiu, utożsamianej z wszystkimi jego wyższymi dążeniami, wydobył bodaj najsilniej wiersz Cienie. Koncepcja miłości wysublimowanej, wyzbytej elementów erotyzmu, a przecież gorącej i żywej, znalazła w tym wierszu wyjątkowo piękny artystycznie wyraz (1963:65).

W utworze tym mowa jest jedynie o wdzięczności kobiety do mężczyzny, która dziękuje za to, że zdołał odmienić jej życie:

Tobie zawdzięczam, że mam tęsknić za czem,

Że mnie ta ziemia czarem swym nie trzyma,

Że się tu czuję przechodniem, tułaczem,

Odkąd tyś mi się w postaci pielgrzyma

Objawił...

I że me życie nie jest pustą kartką,

Choć są w nim miejsca od łez nieczytelne,

Że mi pracować, żyć, cierpieć warto

W imię wszystkiego, co trwa - nieśmiertelnie

Tyś sprawił! (Wolska, 2003:65).

W lirykach Wolskiej najważniejsze jest dotarcie w głąb psychiki kobiety oraz odszyfrowanie jej przeżyć i problemów.

Poetka w wierszu Beata Beatrix przedstawiła postać kobiety sprzeciwiającej się stereotypowemu postrzeganiu jej osobowości ze względu na określenie „Beatrix". Maria Podraza-Kwiatkowska zwróciła uwagę, że: 
[...] głównymi odpowiednikami tego epitetu w języku polskim są „szczęśliwa” lub „błogosławiona”. Obydwa zostają w wierszu dość gwałtownie („Nieprawda!”) odrzucone na rzecz skromnego określenia „prosta dziewczyna” (2011:189).

Bohaterka utworu ujawnia nostalgię i niezadowolenie z życia. Jest w „stanie pośrednim pomiędzy życiem a śmiercią" (Wolska, 2003:191). Twierdzi, że nie ma jej już na ziemi, ale też nie będzie nigdy w niebie. Niczego nie chce i niczego nie potrzebuje. Takie wypowiedzi świadczą o tym, że kobieta pomimo określenia „Beatrix” wcale nie jest szczęśliwa czy błogosławiona. „Autorka wiersza Beata Beatrix, świadoma swego językowego tworzywa, tłumaczy na słowa główny fragment obrazu, to jest ową namalowaną w niecodziennej pozycji, wsłuchaną w siebie postać kobiety" (Podraza-Kwiatkowska, 2011:191). Dwukrotnie pojawia się informacja, że bohaterka opuszcza ramiona, czuje tylko dotyk i słucha samej siebie. Przedmiotem bardzo ważnym do uruchomienia zmysłu słuchu stała się muszla, o której Wolska także dwukrotnie wspomina. Muszla ta jest „ciemna” i „cicha”, a wsłuchując się w nią, można usłyszeć własne potrzeby. W utworze poetka pokazała kobietę słuchającą siebie. Wywyższona została potrzeba indywidualnego bytu, postrzegania siebie jako najważniejszej osoby, odłączenia się od świata i rzeczywistości oraz podążania za własnymi myślami i pragnieniami.

Tematy feministyczne w twórczości Wolskiej to przede wszystkim afirmacja uczuć. Miłość jako podstawowy czynnik wyrażania swoich emocji jest dosyć często obecny w jej utworach. Oprócz tego występują także tęsknota i żal za tym, co przeminęło. Być może kobiety nie zdecydowały się w przeszłości na podjęcie pewnych życiowych decyzji, co z czasem oddziałuje na nie z ogromną siłą. To wszystko może być przyczyną skarg na tkwienie w duszy czegoś nieprzyjemnego, o czym nie pamiętają bądź nie chcą pamiętać. Poetka nie bez powodu podejmowała w lirykach tematykę feministyczną. Autorka wiersza Beata Beatrix pozostawia w swoich utworach ślad tożsamości, ponieważ:

[...] wszędzie tam, gdzie akcentuje się płciowość podmiotu mówiącego, wszędzie tam, gdzie ujawnia się związek między ciałem a tekstem - mamy do czynienia z przypadkiem literatury/ poezji kobiecej (Borkowska, 1995:44).

Ten ślad tożsamości jest widoczny nie tylko w zapisywanym słowie, lecz w czynie lub geście, który wykonuje. Podraza-Kwiatkowska słusznie zauważyła, że:

[...] na własną rękę trzeba było zdobyć świadomość, że w mocno do ucha przyciśniętej muszli słyszy się szmery swego organizmu, słyszy się samego siebie. Właśnie dla tego słyszenia samej siebie, dla aktu samopoznania posłużyła Wolskiej - jak można przypuszczać - nieobecna na obrazie muszla (2011:192). 


\section{BIBLIOGRAFIA}

Borkowska, Grażyna. (1995). Metafora drożdży. Co to jest literatura/poezja kobieca. Teksty Drugie, 3/4 (33/34), s. 31-44.

Borkowska, Grażyna, Książek-Czermińska, Małgorzata, Phillips, Ursula. (2000). Pisarki polskie od średniowiecza do współczesności. Gdańsk: słowo/obraz terytoria.

Cixous, Helene. (1993). Śmiech meduzy. Tłum. Anna Nasiłowska. Teksty Drugie, 4/5/6, s. 147-166. Hutnikiewicz, Artur. (2008). Młoda Polska. Warszawa: Wydawnictwo PWN.

Kozikowska-Kowalik, Lucyna. (1982). Wstęp. W: Kazimiera Zawistowska (red.). Utwory zebrane (s. 5-44). Kraków: Wydawnictwo Literackie.

Kraskowska, Ewa. (1993). Kilka uwag na temat powieści kobiecej. Teksty Drugie, 4/5/6, s. 259-273.

Olech, Barbara. (2002). Marii Grossek-Koryckiej refleksje o kobietach i świecie kobiet. W: Jadwiga Zacharska, Marek Kochanowski (red.). Wiek kobiet w literaturze (s. 243-252). Białystok: Trans Humana.

Pawlikowski, Michał. (1914). O Maryli Wolskiej. Myśl Narodowa, 18, s. 214-217.

Podraza-Kwiatkowska, Maria. (2011). Dante - Rossetti - Maryla Wolska. Opowieść o pewnej ekfrazie. W: eadem. Labirynty - kładki - drogowskazy. Szkice o literaturze od Wyspiańskiego do Gombrowicza (s. 181-195). Kraków: Universitas.

Ritz, German. (1999). Dyskurs płci w ujęciu porównawczym. Teksty Drugie, 5(58), s. 117-123.

Ritz, German. (2000). Modernistyczna liryka kobieca. Od „,nagiej duszy” do duszy kobiety. Kobieca liryka i świadomość feministyczna w polskim modernizmie. Twórczość, 1, s. 57-80.

Sierotwiński, Stanisław. (1963). Maryla Wolska. Środowisko, życie, twórczość. Wrocław-Warszawa-Kraków: Wydawnictwo PAN, Ossolineum.

Smyczyńska, Katarzyna. (2011). Kobiecy przepis na życie. „Babskie czytadła” w optyce feministycznej. W: Filip Pierzchalski, Katarzyna Smyczyńska, Maria Szatlach, Katarzyna Gębarowska (red.). Feminizm po polsku (s. 79-129). Warszawa: Dom Wydawniczy ELIPSA.

Wolska, Maryla, Obertyńska, Beata. (1974). Wspomnienia. Warszawa: PIW.

Wolska, Maryla. (2003). Wiersze wybrane. Kraków: Universitas.

Wydrycka, Anna. (2006). Zapomniane głosy. Krytyka literacka kobiet 1894-1918. T. 1. Białystok: Wydawnictwo Uniwersytetu w Białymstoku.

\section{STRESZCZENIE}

Artykuł przedstawia życie i twórczość jednej z młodopolskich poetek - Maryli Wolskiej. Pierwsza część dotyczy wątków biograficznych w kontekście dylematów pisarki, odnoszących się przede wszystkim do niepewności tworzenia i publikowania własnych dzieł. Część druga wyjaśnia zjawisko liryki kobiecej w oparciu o utwory Wolskiej, natomiast część trzecia przedstawia tematy feministyczne w wybranych lirykach pisarki. Wolska jest dziś poetką zapomnianą pomimo ciekawej i bogatej twórczości. Wszystkie utwory łączy jedna cecha - kobiecość. Artykuł ma na celu przybliżyć sylwetkę oraz twórczość kobiety-poetki piszącej na przełomie XIX i XX wieku.

Słowa klucze: Maryla Wolska, poezja młodopolska, liryka kobieca, poetka, kobiecość, dylematy 


\section{SUMMARY}

The article presents Maryla Wolska's life and work. The first part concerns the biography of Maryla Wolska in the context of her creative dilemmas which concerned the uncertainty of creating and publishing her lyrics. The second and third parts present affirmation of the femininity. In spite of her interesting and rich artistic work, Maryla Wolska is a forgotten poet today. Every poem has one feature - a feminist subject. The article outlines the biography and works of the woman-poet creating at the turn of the $19^{\text {th }}$ and the $20^{\text {th }}$ century, and explains the phenomenon of women's lyric poetry based on her works.

Keywords: Maryla Wolska, poetry of Young Poland, women's lyric, poet, femininity, dilemmas 